\section{LES GRANDES UNIVERSITÉS DE RECHERCHE}

Institutions autonomes dans un environnement concurrentiel

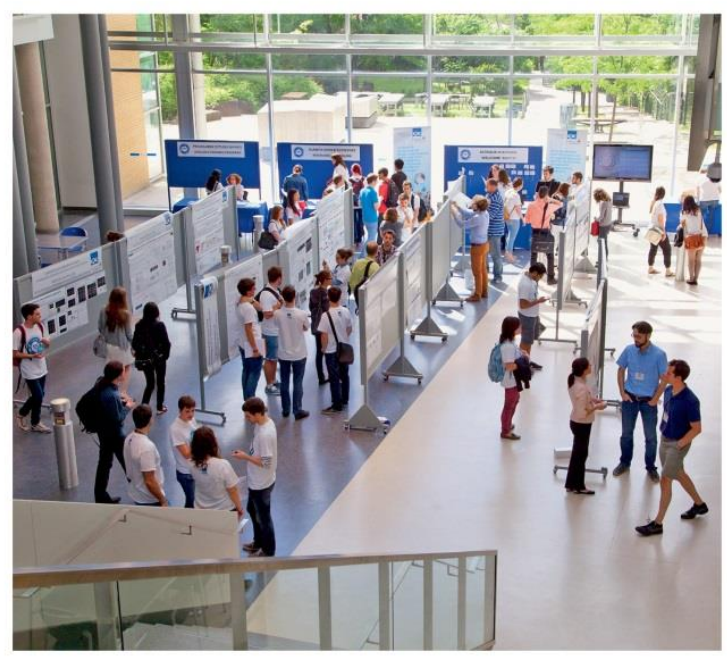

Les Presses de I’Université de Montréal

Pour en savoir plus sur ce livre, feuilleter des pages ou bien le commander, cliquer sur le lien suivant :

http://www.pum.umontreal.ca/catalogue/les-grandesuniversites-de-recherche

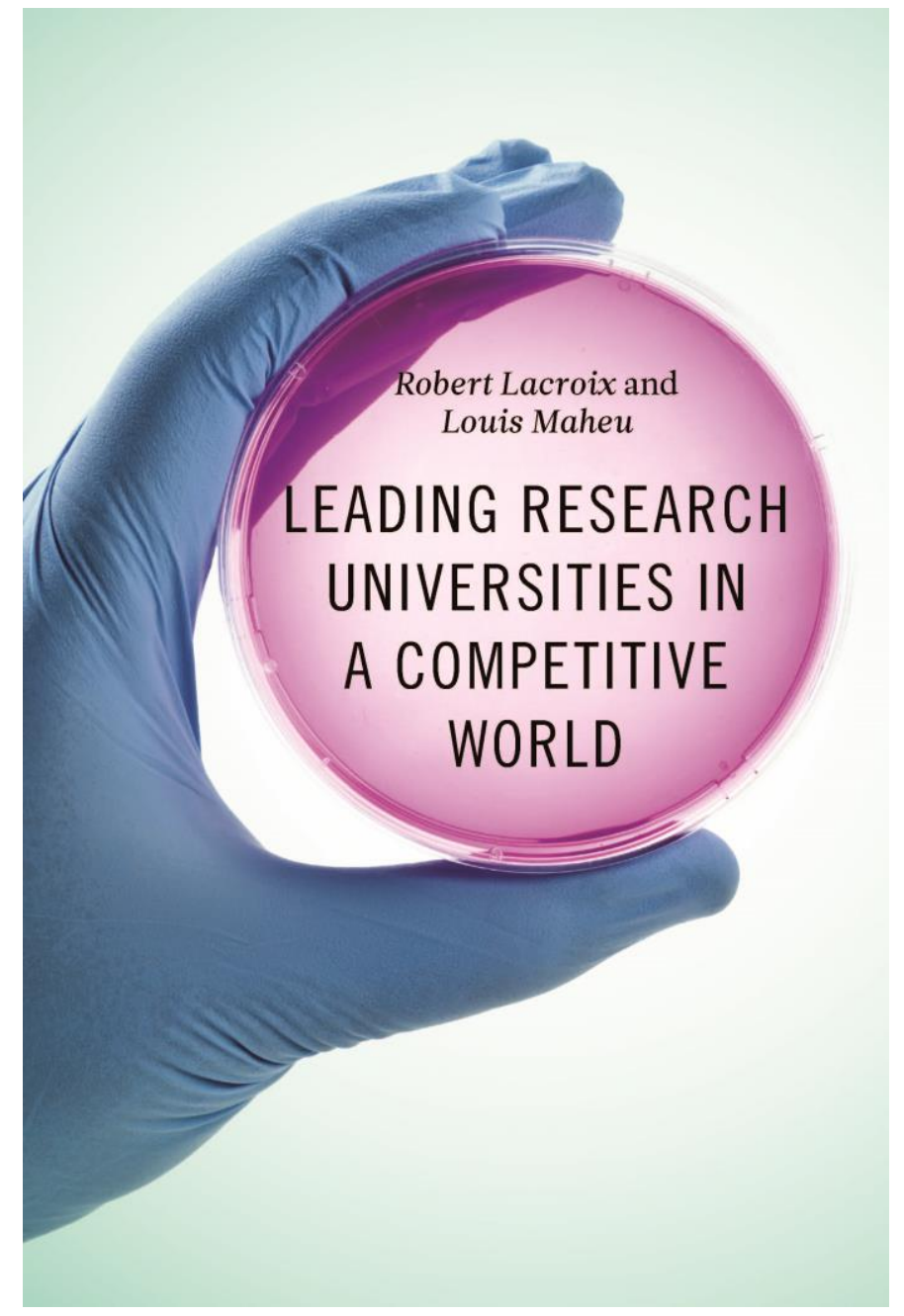

To know more about this book, and to buy it, click on this link: http://www.mqup.ca/leading-researchuniversities-in-a-competitive-world-products9780773544772.php 